\title{
Retraction: Sleep Organisation in Depression and Schizophrenia: Index of Endogenous Periodicity of Sleep as a State Marker
}

\author{
Mirko Spiroski* \\ Faculty of Medicine, Ss Cyril and Methodius University of Skopje, Skopje, Republic of Macedonia
} \begin{abstract}
Citation: Spiroski M. Retraction: Sleep
Organisation in Depression and Schizophrenia: Organisation in Depression and Schizophrenia:
Index of Endogenous Periodicity of Sleep as a State Marker. OA Maced J Med Sci. 2014 Ju $15 ;$ http://dx.doi.org/10.3889/oamjms.2014.055 Key words: Retraction; medical science; PhD; University Psychiatric Clinic; Belgrade; Serbia.

"Correspondence: Prof. Dr. Mirko Spiroski. Faculty of Medicine, Ss Cyril and Methodius University of Skopje, 1109 Skopje, Republic of Macedonia. E-mail: mspiroski@yahoo.com

Received: 09-Apr-2014; Revised: 10-Apr2014; Accepted: 16-Apr-2014; Online first: 17-Apr-2014

Copyright: () 2014 Spiroski. This is an openaccess article distributed under the terms of the Creative Commons Attribution License, which permits unrestricted use, distribution, and reproduction in any medium, provided the original author and source are credited.

Competing Interests: The author have declared that no competing interests exist.
\end{abstract}

\section{Retraction}

The article published by Ilankovic et al., 2013 [1] has been retracted by Editor-in-Chief because corresponding author published the similar paper in Psychiatria Danubina in 2014 [2]. An internal investigation has raised sufficient evidence of the originality in the first paper [1] and self plagiarism in the second paper [2]; as such, we retract this article from the literature on request by corresponding author and in accordance with guidelines and best editorial practices from the Committee on Publication Ethics. We apologize to our audience about this unfortunate situation.

\section{References}

1. Ilankovic A, Damjanovic A, llankovic V, Milovanovic S, Petrovic D, llankovic N. Sleep Organisation in Depression and Schizophrenia: Index of Endogenous Periodicity of Sleep as a State Marker. OA Maced J Med Sci. 2013; 1(1):70-75..

2. Ilanković A, Damjanović A, llanković V, Filipović B, Janković S, llanković N. Polysomnographic sleep patterns in depressive, schizophrenic and healthy subjects. Psychiatr Danub. 2014;26(1):20-6. 